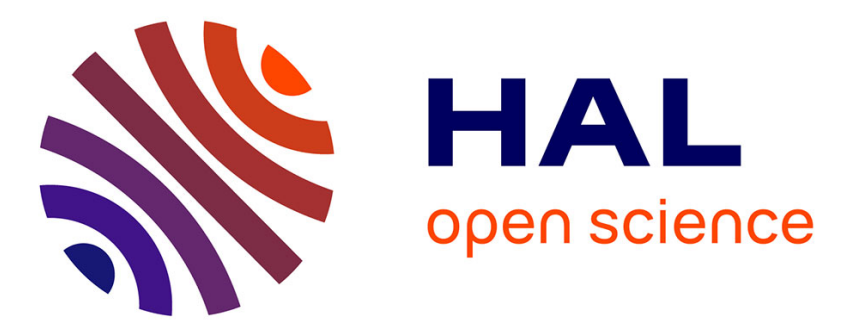

\title{
Managing Buyer-Supplier Relationships in the Maritime Engineer-to-Order Industry
}

Espen Rød, Bjørn Guvåg, Mikhail Shlopak, Oddmund Oterhals

\section{To cite this version:}

Espen Rød, Bjørn Guvåg, Mikhail Shlopak, Oddmund Oterhals. Managing Buyer-Supplier Relationships in the Maritime Engineer-to-Order Industry. IFIP International Conference on Advances in Production Management Systems (APMS), Sep 2015, Tokyo, Japan. pp.183-190, 10.1007/978-3-31922759-7_21.hal-01431093

\section{HAL Id: hal-01431093 https://hal.inria.fr/hal-01431093}

Submitted on 10 Jan 2017

HAL is a multi-disciplinary open access archive for the deposit and dissemination of scientific research documents, whether they are published or not. The documents may come from teaching and research institutions in France or abroad, or from public or private research centers.
L'archive ouverte pluridisciplinaire HAL, est destinée au dépôt et à la diffusion de documents scientifiques de niveau recherche, publiés ou non, émanant des établissements d'enseignement et de recherche français ou étrangers, des laboratoires publics ou privés. 


\title{
Managing Buyer-Supplier Relationships in the Maritime Engineer-to-Order Industry
}

\author{
Espen Rød ${ }^{1}$, Bjørn Guvåg ${ }^{2}$, Mikhail Shlopak ${ }^{3}$, Oddmund Oterhals ${ }^{4}$ \\ 1,3,4 Møreforsking Molde AS, Molde, Norway \\ \{espen.rod, mikhail.shlopak, oddmund.oterhals\}@ himolde.no \\ ${ }^{2}$ Molde University College - Specialized University in Logistics, Molde, Norway \\ bjorn.guvag@himolde.no
}

\begin{abstract}
Norway's shipyards have combined with a large network of maritime suppliers to become world-leading builders of offshore vessels for the oil and gas industry. This study analyzes a Norwegian shipyard and two of its suppliers in order to explore how such relationships are and should be managed. The paper presents an exploratory case study that mainly used qualitative data. The findings indicate that, by following the principles of the inter-organizational theories, the companies will reduce risks and create incentives for better performance. Implementing a real-time information sharing system between the buyer and supplier would improve both operational and managerial performance. The study also suggests that increasing value creation by leveraging the capabilities of the supply network and early involvement of suppliers will have the potential to increase this. Based on the discussion in this study, a performance measurement system for buyer-supplier relationships was developed.
\end{abstract}

Keywords: SCM, inter-organizational management, buyer-supplier relationship, contracts, performance measurement.

\section{Introduction}

Norway's shipyards are considered to be world-leading builders of specialized vessels for the oil and gas industry. The shipbuilding process is project-based with an engineerto-order (ETO) production type. Most projects have a unique technical solution, in which different work-packages are outsourced to other suppliers that perform the actual work [1]. Shipbuilding has similarities with construction, in that the shipyard serves as a construction site where all materials and labor are directed for assembly. The work is done sequentially and executed by different actors. This creates large dependencies between the different tasks and the suppliers; therefore, efficiency - and thus success in shipbuilding - relies on coordination and management of the various actors and activities. This paper addresses the relationships between a Norwegian shipyard and two of its suppliers. The main deliveries from these suppliers are services such as surface treatment and interior work. The supply chain of services is different from other supply chains as many decisions are made locally, and the variation and uncertainties in output 
are higher because of human involvement [2]. The four roles of supply chain management (SCM) in construction were defined by [3], and the present study focuses on the first of these roles, which is the interface between the supply chain and the construction site. The idea behind this role is reducing the cost and duration of site activities and ensuring dependable material and labor flows to the site to avoid disruptions. The purpose of the present study is to identify how buyer-supplier relationships in an ETO and construction environments are and should be managed. Part of this involves determining how companies can leverage the competences and capabilities of each of the actors in the chain to improve efficiency of the shipbuilding process and create an environment that encourages innovation and improvements. We have also tried to identify how the performance of such relationships can be measured and improved. This paper is a part of the SMARTprod research project conducted by one of the Norwegian shipyards and Møreforsking Molde AS.

\section{$2 \quad$ Literature}

The literature presents several areas related to buyer-supplier relationships, including SCM, inter-organizational (IO) topics, co-creation of value, contracts, and the measurement of performance in buyer-supplier relationships. One of the most significant paradigm shifts of modern business management is that individual businesses no longer compete as solely autonomous entities, but as supply chains [4]. Within IO topics, principal-agent theory, transaction cost theory, resource dependence theory, and the resource-based view have been used to highlight the different mechanisms that affect business relationships. Principal-agent theory identifies certain risk factors, based on human and organizational assumptions and how the possible negative effects such as adverse selection and moral hazard can be reduced [5]. Transaction cost theory aims to find the governance form that keeps the transaction cost at the lowest possible level [6]. Resource dependence theory proposes that organizations participate in exchange relationships to procure resources, as very few organizations are self-sufficient with regard to strategic and critical resources, and therefore seek to reduce uncertainty and manage their dependence on other companies [7]. The resource-based view looks at how one company's superior resources can create a competitive advantage [8].

It is not only dyadic relationship that is important, but also the context in which the dyad takes place. A company must relate its activities to those of other firms in order to enhance its performance. Combining and recombining the resources within the supply network creates and develops new dimensions of resources [9]. These are dynamic capabilities, which are defined as "the firm's ability to integrate, build and reconfigure internal and external competences to address rapidly changing environments" [10].

Several authors, especially within the IO field, have discussed value creation in buyer-supplier relationships, and IO theories are central to achieving this. Borys and Jemison saw value creation as a joint effort in which value is created in the interaction when one firm's competitive advantage is improved [11]. Dyer and Singh focused on value that can only be created through the joint idiosyncratic contributions of the specific alliance partners [12]. Ghosh and John considered value creation to be the increasing of revenue through positioning (what the company chooses to produce and deliver 
to the customer) and the company's resources, while reducing cost through an effective governance form [13]. Companies undertake value creation initiatives in order to achieve value creation. While Ghosh and John saw such initiatives as "in-house" activities that buyers want their suppliers to perform in order to achieve value creation at the relationship level [13], Borys and Jemison, as well as Hammervoll, argued that value creation initiatives are learning and development within the relationship [11], [14].

Contracts are also an essential element of a buyer-supplier relationship. The development of appropriate contracts is a key to creating an environment for innovations and continuous improvements. The contracts can be categorized as either discrete or relational. In discrete relationships, the organization's focus is on individual gains from the transaction, while in relational exchange the focus is on mutual benefits from a relationship on longer terms [15]. When it comes to duration, a short-term contract can have a negative impact on the supplier's motivation to invest in competence development. However, a long-term contract does not necessarily ensure an environment for continuous improvements and can dampen the innovation potential with the supplier as the supplier is somewhat protected from competition for the contracted duration [15]. Fixed price and payments for time spent and material used both have positive and negative sides. The latter will motivate the supplier to focus mostly on the contracted activities, and not on finding innovative solutions to improve efficiency. In fixed price contracts, the supplier is in a self-motivating situation to improve contract execution efficiency and focus on continuous improvements [15].

In order to track performance and be able to improve in IO relationships, the performance must be measured. As relationships of this kind are cooperative and flexible, measures of both qualitative and quantitative should be included [15]. Appropriate supply chain measurements should be selected and assessed to ensure that outcomes and strategy are aligned and fit the industrial application [16]. To develop such a measurement system for buyer-supplier relationships, the balanced scorecard (BSC) is used [17]. The BSC, which was originally based on a company's vision and strategy, measures the four following dimensions: financial, customer, internal business processes, and learning and growth. Brewer and Speh suggested linking this to SCM by changing the dimensions into financial benefits, customer benefits, SCM goals, and SCM improvements [18]. Important metrics for evaluating partnerships are the level and degree of information sharing, buyer-supplier cost saving initiatives, mutual cooperation leading to improved quality, the entity and stage at which the supplier is involved, and the extent of mutual assistance in problem solving efforts [19].

\section{$3 \quad$ Research methodology}

This paper presents an exploratory case study of a Norwegian shipyard and two of its suppliers. The scarcity of previous research in this field in the Norwegian maritime industry created the need for an exploratory study. The purpose was to gain a better understanding of how IO relationships are managed in this industry and compare it to the literature within IO management. Based on an initial literature review, an interview guide was developed and interviews conducted. A second round of literature review 
and a final interview guide was then developed and further interviews conducted. Ten semi-structured interviews were carried out, six at the focal firm and two at each of the suppliers. To secure a reliable and valid research, several interviews were held with employees in different disciplines at both the shipyard and at the suppliers.

\section{$4 \quad$ Analysis}

The variation of output in service supply chains is higher than other supply chains due to the human involvement factor. Much of the work carried out in the shipyard is done manually, and leads to variation in the time spent performing the tasks. The flow of information is found to be one of the most important elements in the supply chain of services. The degree of uncertainty involved means that it is also necessary to have high levels of collaboration and transparency to improve operational performance and reduce disruptions in the chain [2]. It is vital to reduce the time to outfit and disruptions and make improvements in operations.

Adverse selection arises ahead of the time at which the suppliers are chosen. If the shipyard decided to switch suppliers, it will find itself in a situation with asymmetrical information and will not know whether the new supplier has the same capabilities as the old one. Moral hazard is linked to ongoing relationships, and the question is whether the supplier will actually deliver the effort that was agreed upon. The shipyard controls the quality of all the work done by the suppliers before an area or a task is approved. By paying a fixed price per square meter, the shipyard is able to reduce the risk as it will gain the supplier to have the work approved the first time.

These two types of relationships are regarded as hybrid governance forms [6]. This mode works well when the need for cooperative adaptations is vital for an efficient operation and there is a strong need for administrative control. Investments that are made to improve the relationship (for example, specific assets) are among the attributes of buyer-supplier relationships. Investments can reduce transaction costs, but the actors are vulnerable to a locked-in situation. Another attribute is high frequency and long duration. The suppliers work at the shipyard almost every day. Due to general practice, minor problems and delays are usually handled by the workers and the foremen and are not enforced by the contract. Another attribute is uncertainty about the conditions that will prevail. Because of the complexity of the ship, it is both difficult and inefficient to plan for every contingency. Errors in plans or the engineering will occur during the building process. To secure smooth operations in spite of these occurrences, a price is paid for work outside of the scope, which creates flexibility. The main attribute that raises transaction cost is the connectedness and dependencies between tasks and activities and between the different suppliers.

\subsection{Network and value creation}

Some examples of combining and recombining of resources were found in the study, such as the cooperation between the shipyard and the supplier of surface treatments and their paint supplier. The paint supplier uses the ships to test new types of paint, whereas 
the supplier performs this work and receives training from its supplier. This can be seen as a reconfiguration of resources, which is one of the clusters of dynamic capabilities.

Leveraging a capability involves replicating a process or system from one business unit to another or extending a resource into a new domain. The interviews revealed that the interior supplier uses a Microsoft Excel-based system to continuously track its current progress in each task it performs on a day-to-day basis. The supplier only uses this system to track its own performance and the information is only shared through the weekly planning meetings. By allowing the shipyard's planning department access to the system, the shipyard would be able to track the achievement of each task in real time. This would enable it to make better plans and operate more efficiently by avoiding delays, executing early starts and making more effective use of resources.

The third cluster of dynamic capabilities is learning, which allows tasks to be performed more efficiently as an outcome of experimentation. Through their work, the supplier's workers gain knowledge of the shipbuilding process. Without a system that captures the performing experiences, knowledge will be lost. Only a few of the suppliers participate in the project evaluation, which can lead to vital knowledge being lost.

Creative integration is the fourth cluster of dynamic capabilities. This concerns the ability to integrate the assets and resources of the firms, which results in a new resource configuration [10]. The shipyard may integrate more of the resources of its interior supplier, which is part of a multinational cooperation that is able to source many effective and high-quality solutions. However, the supplier rarely has the opportunity to discuss this due to a strong focus on the current project. Earlier involvement of the suppliers will make discussions of future improvements possible.

\subsection{Contracts}

The shipyard has framework agreements with both of the suppliers. These contracts last for three years at a time and stipulate all prices for the different types of work.

In terms of maintenance and service, it is suggested that the relationships should be relational rather than discrete, as the need for cooperation is high during contract execution [15]. The relationships studied here should be regarded as relational, as problems that occur in the project are usually solved without referring to the contract. There is a high degree of flexibility and the main focus from both parties is to get the work done and to deliver on time. The respondents claim that the complexity means that close cooperation between the parties and flexibility is essential. For additional work that is not planned for in the scope, the contract includes an hourly price to safeguard the suppliers against this risk.

With a three-year contract, the suppliers are involved in at least nine projects, which provides incentives to invest in competence development and new technologies to improve. As they have an outcome-based contract where prices are fixed, any improvements will reduce their cost per square meter. A long-term contract has the potential to reduce continuous improvements and dampen innovation due to protection from competition, which means that buyers must be safeguarded against this contingency [15]. The use of a fixed price per square meter is one way to dampen this effect, as it is in 
the supplier's own interest to improve, given that reducing their relative costs per square meter will increase their profit.

One of the respondents at the supplier mentioned that risks are improperly distributed in some areas and provide a specific example. The shipyard has an accommodation unit for the workers to stay in when working at the shipyard. The suppliers pay a fixed price to rent this unit. However, they do not guarantee places for all the workers, meaning that the suppliers might need alternative arrangements. Because the suppliers do not know whether they will need these alternatives, or to what extent and at what price, they must include a risk premium. This results in a higher price to the buyer and shows the importance of having a correct risk apportionment between the buyer and supplier, and of continuously reviewing these risks to improve the conditions for the relationship.

\subsection{Performance Measurement}

The literature review revealed the adaptation of BSC to SCM. To measure performance in buyer-supplier relationships, this has further been adapted.

Table 1. Balanced scorecard adapted to business relationships.

\begin{tabular}{lll}
\hline \multicolumn{1}{c}{ Original } & \multicolumn{1}{c}{ SCM } & Business relationships \\
\hline Financial dimension & Financial benefits & Financial benefits \\
\hline Customer dimension & Customer benefits & Customer benefits \\
\hline Internal business processes & SCM goals & Relationship goals \\
\hline Learning and growth & SCM improvements & Relationship improvements \\
\hline
\end{tabular}

The level and degree of information sharing was mentioned as an important partnership evaluation criterion. The interviews revealed several challenges, including the delays caused by high interdependence between activities about which the suppliers are not informed. Measuring the number of times a delay occurs where information about it was not shared beforehand will highlight the importance of information sharing and can help identify where the delays originate.

Another partnership metric is mutual cooperation leading to improved quality. Delays are mainly caused by low quality of the steel. This problem needs to be solved in cooperation, as it is the shipyard that should control the steel. An example for the performance metric here is to measure the number of times finished work must be redone.

A further criterion is the entity and stage at which the supplier is involved. In particular, the interior supplier says it should be included at an earlier point in the presales phase in order to discuss solutions it can provide. This measurement could lead to improvements in terms of delivery of the work, products, and other solutions from the suppliers.

Buyer-supplier cost saving initiatives can be measured within the financial benefits in the BSC. A suitable measure is the number of hours paid to suppliers that are not caused by change-orders from the customer, but by delays or rework.

Finally, a measure is needed for customer benefits in the BSC. The ship-owner, which is the customer, continuously controls the work done through the project and 
approves and signs off areas that are ready. The ship-owner often finds something that must be repaired later and must therefore control an area several times. An example of a measurement for customer benefit could be whether the customer can sign off on the room the first time they control it. Figure 1 shows the specific BSC developed for measuring the performance of these two buyer-supplier relationships.

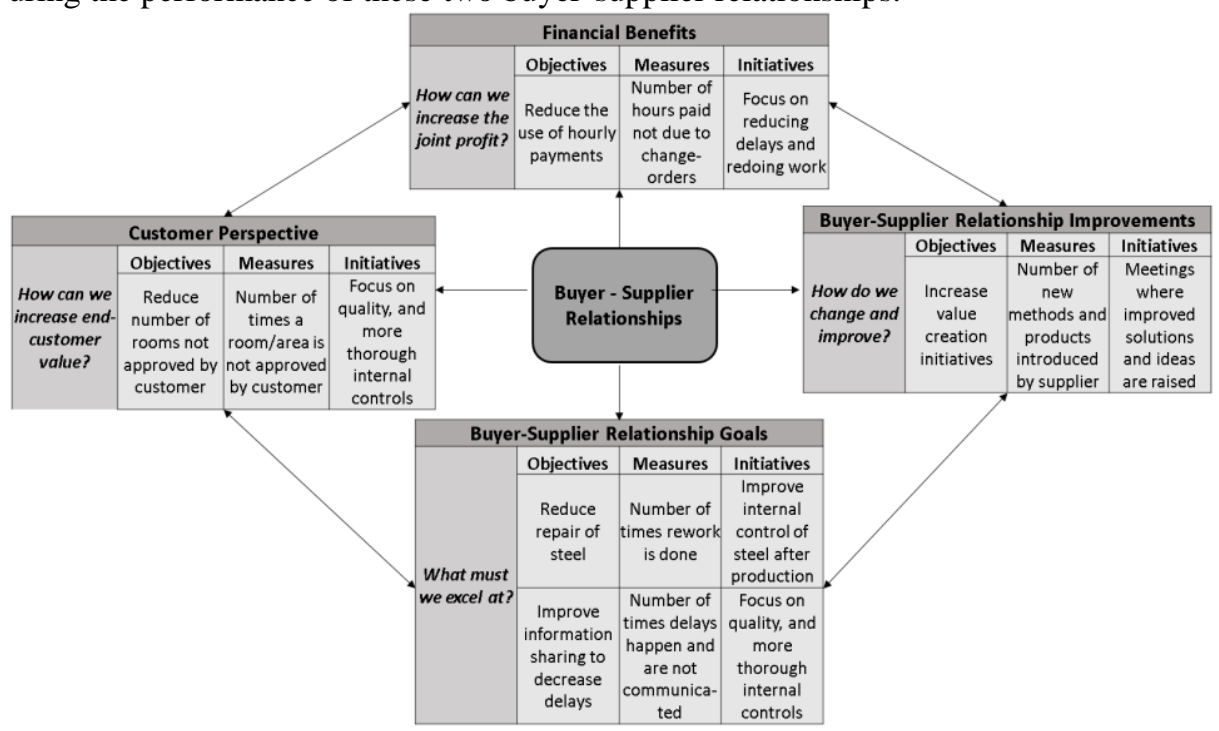

Fig 1. Balanced scorecard for buyer-supplier relationships.

\section{Conclusion}

This study has explored the relationship between a Norwegian shipyard and two of its suppliers. The analysis showed that having all three actors share the same goals, as well as having control mechanisms and a fixed price contract, have mitigated many hazards and negative consequences related to buyer-supplier relationships. These features have also reduced transaction costs through investing in the relationship, and having relationships with a high transaction frequency and a long duration. Problems related to uncertainty in these kinds of relationship have been solved through having a fixed price for planned work, and an hourly price for additional unplanned or extra work. By doing this they will remain flexible, which is important to remain competitive in ETO production. The features discussed here are all important when managing any buyer-supplier relationship in an ETO environment. Some issues were found to be less optimal. One problematic issue was found in relation to communication and information sharing. Having shared access to the information systems the suppliers currently use could be one way to minimize the loss of important information. In addition, a clearer chain of information should be developed, and a higher focus on the importance of information sharing should be communicated widely. Information sharing and systems for achieving these points should have a high focus in the management of buyer-supplier relationships. 


\section{References}

1. Aslesen, S., Den maritime klynga i bevegelse. Fafos Rådsprogram, 2006.

2. Sengupta, K., D.R. Heiser, and L.S. Cook, Manufacturing and service supply chain performance: a comparative analysis. Journal of Supply Chain Management, 2006. 42(4): pp. 4-15.

3. Vrijhoef, R. and L. Koskela, The four roles of supply chain management in construction. European journal of purchasing \& supply management, 2000. 6(3): pp. 169-178.

4. Lambert, D.M. and M.C. Cooper, Issues in supply chain management. Industrial marketing management, 2000. 29(1): pp. 65-83.

5. Eisenhardt, K.M., Agency theory: An assessment and review. Academy of management review, 1989. 14(1): pp. 57-74.

6. Williamson, O.E., Outsourcing: Transaction cost economics and supply chain management* Journal of supply chain management, 2008. 44(2): pp. 5-16.

7. Paulraj, A. and I.J. Chen, Environmental uncertainty and strategic supply management: a resource dependence perspective and performance implications. Journal of Supply Chain Management, 2007. 43(3): pp. 29-42.

8. Peteraf, M.A., The cornerstones of competitive advantage: a resource-based view. Strategic management journal, 1993. 14(3): pp. 179-191.

9. Gadde, L.-E., L. Huemer, and H. Håkansson, Strategizing in industrial networks. Industrial Marketing Management, 2003. 32(5): pp. 357-364.

10. Teece, D.J., G. Pisano, and A. Shuen, Dynamic capabilities and strategic management. Strategic Management Journal, 1997. 18(7): pp. 509-533.

11. Borys, B. and D.B. Jemison, Hybrid arrangements as strategic alliances: Theoretical issues in organizational combinations. Academy of management review, 1989. 14(2): pp. 234-249.

12. Dyer, J.H. and H. Singh, The relational view: Cooperative strategy and sources of interorganizational competitive advantage. Academy of management review, 1998. 23(4): pp. 660-679.

13. Ghosh, M. and G. John, Governance value analysis and marketing strategy. The Journal of Marketing, 1999: pp. 131-145.

14. Hammervoll, T., Value-creation logic in supply chain relationships. Journal of Business-toBusiness Marketing, 2009. 16(3): pp. 220-241.

15. Singh Panesar, S. and T. Markeset, Industrial service innovation through improved contractual relationship: A case study in maintenance. Journal of Quality in Maintenance Engineering, 2008. 14(3): pp. 290-305.

16. Elrod, C., S. Murray, and S. Bande, A Review of Performance Metrics for Supply Chain Management. Engineering Management Journal, 2013. 25(3): pp. 39-50

17. Kaplan, R.S. and D.P. Norton, Using the balanced scorecard as a strategic management system. Harvard business review, 1996. 74(1): pp. 75-85.

18. Brewer, P.C. and T.W. Speh, Using the balanced scorecard to measure supply chain performance. Journal of Business logistics, 2000. 21(1): pp. 75-93.

19. Gunasekaran, A., C. Patel, and E. Tirtiroglu, Performance measures and metrics in a supply chain environment. International journal of operations \& production Management, 2001. 21(1/2): pp. 71-87. 